\title{
Fatigue dan status nutrisi pada pasien dengan kanker payudara yang menjalani kemoterapi
}

\author{
Sapti Ayubbana ${ }^{1}$, Sari Narulita ${ }^{2}$ \\ 1Akademi Keperawatan Dharma Wacana Metro. Email: Sapti.ayubbana@gmail.com \\ 2Program Studi Keperawatan Universitas Binawan Email: sari@binawan.ac.id
}

\section{Abstract \\ Fatigue and nutritional status in patients with breast cancer undergoing chemotherapy}

Background: Breast cancer is one type of cancer and is one of the leading causes of death in the world. Cancer patients who receive chemotherapy are at risk of impaired nutritional status due to the disease and its treatment. Chemotherapy treatment can have side effects on the gastrointestinal system such as nausea, vomiting, stomatitis, anorexia, changes in taste. These side effects can cause the patient's nutritional intake to decrease. Cancer and its treatment can cause fatigue complaints.

Purpose: to identify the relationship between fatigue and nutritional status in patients with breast cancer patients undergoing chemotherapy

Methods: The design of this study was quantitative using a cross sectional approach. The population in this study were patients with breast cancer undergoing chemotherapy. This research was conducted at Dr.H. Abdul Moeloek Hospital of Lampung Province with 42 respondents.

Results: Spearman correlation test results found that nutritional status variables have a significant relationship with fatigue ( $p$ value $=0.031)$ with moderate correlation strength $(r=0.471)$.

Conclusion: The nursing intervention on the side effects of chemotherapy treatment which has a positive effect on nutritional conditions in an effort to overcome nutritional disorders and complaints of fatigue in cancer patients.

\section{Keywords: Breast Cancer; Chemotherapy; Fatigue; Nutritional Status}

Pendahuluan: Kanker payudara merupakan salah satu jenis kanker dan menjadi salah satu penyebab kematian di dunia. Pasien kanker yang menerima kemoterapi memiliki resiko gangguan status nutrisi akibat penyakit dan pengobatannya. Pengobatan kemoterapi dapat memberikan efek samping terhadap sistem ganstrointestinal seperti mual, muntah, stomatitis, anoreksia, perubahan rasa. Efek samping tersebut dapat menyebabkan asupan nutrisi pasien dapat mengalami penurunan. Kanker dan pengobatannya dapat menyebabkan keluhan fatigue.

Tujuan: Mengetahui adanya hubungan antara status nutrisi terhadap fatigue pada pasien kanker payudara yang menjalani kemoterapi.

Metode: Desain penelitian ini adalah kuantitatif dengan menggunakan pendekatan cross sectional . Populasi pada penelitian ini adalah pasien dengan kanker payudara yang menjalani kemoterapi. Penelitian ini dilakukan di RSUD Dr.H. Abdul Moeloek Provinsi Lampung dengan 42 responden.

Hasil: Pada uji korelasi spearman didapatkan bahwa variabel status nutrisi mempunyai hubungan yang bermakna dengan fatigue ( $p$ value $=0,031)$ dengan kekuatan korelasi sedang $(r=0,471)$.

Simpulan: Kesimpulan diperlukan intervensi keperawatan terhadap efek samping pengobatan kemoterapi yang berdapak terhadap kondisi nutrisi dalam upaya mengatasigangguan nutrisi dan keluhan fatigue pada pasien kanker

\section{Kata kunci: Fatigue; Kanker Payudara; Kemoterapi; Status Nutrisi}

\section{PENDAHULUAN}

Kanker payudara merupakan salah satu jenis kanker dan menjadi salah satu penyebab kematian di dunia. Insiden kanker payudara menduduki posisi pertama jenis kanker yang ditemui pada wanita. Insiden kanker payudara di Indonesia 
Fatigue dan status nutrisi pada pasien dengan kanker payudara yang menjalani kemoterapi

sebesar $48.998(30,5 \%)$ dengan angka mortalitas sebesar 19.750 (30,5\%) (International Agency for Research on Cancer, 2012). Prevalensi kanker di Indonesia menunjukkan 1,4 per 1000 penduduk (Kementerian Kesehatan Republik Indonesia, 2013).

Kanker berupa proliferasi berlebih pada sel yang kurang memiliki kemampuan fungsi normal (Rosdahl \& Kowalski, 2012). Kanker dapat terjadi di payudara dan menyebabkan keganasan di jaringan payudara. Keganasan terjadi ketika sel-sel di jaringan payudara mulai tumbuh diluar kendali (American Cancer Society, 2016). Pengobatan kanker dapat bertujuan sebagai penyembuhan, menghambat pertumbuhan sel-sel kanker, atau hanya menghilangkan gejala yang ditimbulkan oleh kanker. Metode pengobatan kanker payudara meliputi operasi, radioterapi, bioterapi, terapi hormonal dan kemoterapi (Black \& Hawks, 2014).

Pasien kanker yang menerima kemoterapi memiliki resiko gangguan status nutrisi akibat penyakit dan pengobatannya. Pengobatan kemoterapi dapat memberikan efek samping terhadap sistem ganstrointestinal seperti mual, muntah, stomatitis, anoreksia, perubahan rasa. Efek samping tersebut dapat menyebabkan asupan nutrisi pasien dapat mengalami penurunan (Black \& Hawks, 2014). Terdapat $40-80 \%$ pasien kanker mengalami berbagai kekurangan gizi (Sánchez, Ugalde, Motola, \& Green, 2013). Salah satu screening untuk mengidentifikasi status nutrisi dengan menggunakan malnutrisi screening tools (MST). MST terdiri dari dua pertanyaan yaitu menanyakan penurunan berat badan, berapa penurunan berat badan dan apakah asupan berkurang karena mengalami tidak nafsu makan. Bila skor MST $\geq 2$ maka pasien beresiko kekurangan gizi dan perlu segera mendapatkan intervensi nutrisi dan konsultasi dengan ahli gizi (Ferguson, Capra, Bauer, \& Banks, 1999).

Kanker dan pengobatannya dapat menyebabkan keluhan fatigue. Fatigue perasaan subjektif atas kelelahan fisik, kognitif, emosional berkaitan dengan kanker atau pengobatan kanker dan kelelahan yang dirasakan tidak sebanding dengan aktifitas yang dilakukan (National
Comprehensive Cancer Network, 2012). Terdapat sekitar 50\% hingga $90 \%$ pasien kanker mengalami fatigue, dengan $90 \%$ mewakili pasien yang sedang dalam pengobatan kanker seperti kemoterapi dan radioterapi (Campos, Hassan, Riechelmann \& Giglio, 2011).

Fatigue pada pasien kanker dapat berkisar dari ringan sampai berat (Miaskowski \& Aouizerat, 2014). Alat ukur fatigue pada pasien kanker dapat menggunakan berbagai macam instrumen, salah satunya adalah Brief Fatigue Inventory (BFI). BFI merupakan instrumen singkat, valid dan reliabilitas menilai fatigue pasien kanker (Paramita, 2015).

\section{METODE PENELITIAN}

Jenis penelitian ini adalah kuantitatif menggunakan pendekatan cross sectional. Populasi yaitu pasien kanker yang menjalani kemoterapi di unit pelayanan kemoterapi di RSUD Dr. H. Abdul Moeloek provinsi Lampung, berjumlah 42 responden dengan kriteria inklusi pasien kanker yang menjalani kemoterapi serta mengalami keluhan fatigue. Variabel independen adalah pasien kanker dan variabel dependen adalah fatigue. Alat pengumpul data dalam penelitian ini menggunakan kuesioner, malnutrisi screening tools (MST), dan Brief Fatigue Inventory (BFI). Instrumen BFI dikembangkan dari penelitian sebelumnya dengan nilai koefisien cronbach alpha adalah 0,93 (Mendoza, Wang, Cleeland, Morrissey, Johnson, Wendt, \& Huber, 1999). Uji validitas konvergen dengan membandingkan skor BFI dengan sub skala MOS SF-36 $(p<0,0000)$ dan uji realibilitas versi bahasa Indonesia menunjukkan bahwa cronbach alpha versi bahasa Indonesia adalah 0,956 (Paramita, 2015). Berdasarkan skor yang didapatkan, fatigue dapat dikatagorikan atas tidak fatigue bila skor yang didapatkan 0 , fatigue ringan dengan skor yang didapat: 1-3, fatigue sedang bila skor: 4-6, dan fatigue berat bila skor yang didapatkan: 7 - 10 (National Comprehensive Cancer Network, 2014). Pengumpulan data dilakukan oleh peneliti sendiri. Data yang didapat dianalisa dengan menggunakan SPSS versi 21 secara univariat dan bivariate. 
HASIL

Tabel 1. Distribusi Karakteristik Responden $\mathrm{N}=42$

\begin{tabular}{|c|c|c|}
\hline Variabel & Frekuensi (f) & Persentase (\%) \\
\hline \multicolumn{3}{|l|}{ Stadium Kanker } \\
\hline a. 1 & 3 & 7,14 \\
\hline b. 2 & 12 & 28,57 \\
\hline c. 3 & 27 & 64,29 \\
\hline \multicolumn{3}{|l|}{ Obat Kemoterapi } \\
\hline a. Regimen CAF & 38 & 90,48 \\
\hline b. Regimen Lain & 4 & 9,52 \\
\hline \multicolumn{3}{|l|}{ Siklus Kemoterapi } \\
\hline a. Siklus 1 & 38 & 90,48 \\
\hline b. Siklus 2 & 2 & 4,76 \\
\hline c. Siklus 3 & 2 & 4,76 \\
\hline
\end{tabular}

Tabel 1 diatas menunjukkan bahwa sebagian besar stadium 3 ( 64,29\%), obat kemoterapi yang digunakan responden sebagian besar menggunan regimen CAF $(90,48 \%)$, siklus kemoterapi responden sebagian besar siklus I $(90,48 \%)$,

Tabel 2. Analisis Hubungan Status Nutrisi Dengan Fatigue $\mathbf{N}=42$

\begin{tabular}{lcc}
\hline \multirow{2}{*}{ Variabel } & \multicolumn{2}{c}{ Fatigue } \\
\cline { 2 - 3 } & \multicolumn{1}{c}{$p$} & $p$-value \\
\hline Status nutrisi & 0,471 & 0,031
\end{tabular}

Tabel 2 diatas menunjukkan hasil uji korelasi spearman didapatkan bahwa variabel status nutrisi mempunyai hubungan yang bermakna dengan fatigue ( $p$ value $=0,031$ ) dengan kekuatan korelasi sedang $(r=0,471)$.

\section{PEMBAHASAN}

Penelitian ini mengidentifikasi hubungan kualitas tidur dengan fatigue pada pasien kanker yang menjalani kemoterapi. Hasil analisis uji korelasi spearman didapatkan hasil adanya hubungan antara status nutrisi dengan fatigue ( $p$ value $=0,031)$. Hal ini relevan dengan hasil penelitian sebelumnya yang menyatakan bahwa terdapat hubungan antara status nutrisi dengan fatigue ( $p$ value $<0,01)$ (Wei \& Li, 2017).

Sel kanker tumbuh dan berkembang secara tidak terkendali dalam tubuh dan memerlukan nutrisi untuk tumbuh dan berkembang (Black \& Hawks, 2014). Ketika menghadapi ketidakcukupan pemasukan energi melalui makanan dalam waktu yang panjang, tubuh menguraikan protein otot untuk memenuhi kebutuhan pengeluaran energi
(Sherwood, 2014). Dampak yang ditimbulkan dari defisit suplai nutrisi yaitu penipisan jaringan adiposa, hilangnya masa otot. Dampak malnutrisi ini tercemin dari menurunnya berat badan (Black \& Hawks, 2014). Berdasarkan malnutrisi screening tools (MST) didapatkan bahwa penurunan berat badan pasien selama 6 bulan terakhir menunjukkan bahwa penurunan $>5 \mathrm{~kg}$ sebesar $40,8 \%$, dan skor MST $\geq 2$ sebanyak $11,90 \%$. Hal ini relevan dengan penelitian sebelumnya yang menyatakan bahwa rerata responden mengalami penurunan berat badan sebesar $7,1 \%$ dan mengalami penurunan berat badan $\geq 10 \%$ sebanyak 38,3 \% (Mariani, Vullo, \& Bozzetti, 2012).

Berdasarkan malnutrisi screening tools (MST) $70 \%$ responden menyatakan bahwa intake nutrisi 
Fatigue dan status nutrisi pada pasien dengan kanker payudara yang menjalani kemoterapi

yang kurang karena tidak nafsu makan. Pasien kanker mengalami penurunan pemasukan energi akibat perubahan nafsu makan dan efek samping pengobatan. Efek samping pengobatan seperti anoreksia, cachexia dapat mempengaruhi metabolism protein. Kanker dan pengobatannya dapat menyebabkan kerusakan pada regenerasi ATP dan penumpukan hasil metabolisme sampingan dalam sambungan neuromuskular dan otot skelet. Gangguan metabolisme ATP pada pasien kanker dapat menurunkan kemampuan melakukan aktifitas mekanik (Ryan, Carroll, Mustian, Fiscella, Morrow, 2007; Wang, 2008).

Berdasarkan analisis univariat menunjukkan bahwa rerata usia responden 48,38 tahun. Hal ini menunjukkan bahwa ada responden masuk dalam kriteria usia lanjut. Menurut teori bahwa ada beberapa perubahan yang terjadi selama proses penuaan yang dapat memfasilitasi terjadinya fatigue yaitu berupa perubahan proses pencernaan yang dapat menurunkan asupan nutrisi (Reiner, \& Lacasse, 2006). Perubahan fisiologis berupa akuitas rasa dapat menurunkan sesuai usia; Penurunan normal pada sekresi lambung menyebabkan kurangnya efisiensi digesti (Potter \& Perry, 2006).

Berdasarkan analisis univariat menunjukkan bahwa sebagian besar responden stadium III. Stadium kanker merupakan tingkatan keparahan kanker responden yang di tunjukan dari penampilan anatomi kanker. Stadium kanker berdasarkan hasil penilain dari sistem TNM. Sistem TNM menilai besarnya tumor $(T)$, keterlibatan kelenjar getah bening $(\mathrm{N})$ dan metastase (M). Berdasarkan hasil analisis univariat bahwa sebagian besar responden dalam stadium 3 , hal ini menunjukkan bahwa berdasarkan sistem TNM nilai T berkisar T0 - T4 artinya ukuran tumor responden antara ukuran yang tidak dapat dinilai hingga tumor sudah menembus dinding dada atau kulit. Berdasarkan sistem TNM nilai $\mathrm{N}$ berkisar antara N1-N2 artinya penyebaran sel kanker telah menyebar hingga kelenjar ipsilateral hingga limfe mamaria interna. Berdasarkan sistem TNM nilai M menunjukkan MO artinya belum ada metastase jauh. Kondisi ini menunjukkan bahwa pertumbuhan kanker yang pesat dan banyaknya penggunaan nutrisi tubuh untuk perkembangan sel kanker (American Joint Committee on Cancer, (2010).

Berdasarkan analisis univariat menunjukkan bahwa sebagian responden menggunakan regimen CAF (cyclophosphamide, dexorubisin, fluorourasil). Berdasarkan teori yang relevan bahwa obat cylophosphamide merupakan obat kemoterapi golongan alkilator yang bekerja dengan mentrasfer gugus alkilnya ke berbagai komponen sel sehingga menyebabkan struktur sel rusak. Obat cyclophosphamide memberikan efek samping depresi sumsum tulang dan mual muntah. Obat dexorubisin merupakan obat golongan antibiotik bekerja dengan cara menyusup masuk kepasangan DNA mengakibatkan terpisahnya rangkaian ganda DNA. Obat dexorubisin memberikan efek samping depresi sumsum tulang dan mual muntah. Sedangkan obat fluorourasil merupakan obat kemoterapi golongan anti metabolit yang bekerja mempengaruhi metabolisme metabolisme asam nukleat dan makomolekul protein. Obat fluorourasil memberikan efek samping berupa depresi sumsum tulang, mukositis, dan mual muntah (Polovich, Whitford, \& Olsen, 2008). Berdasarkan uraian diatas bahwa obat cyclophosphamide, dexorubisin fluorourasil memiliki efek samping berupa depresi sumsum tulang yang dapat menurukan produksi eritrosit dan mual muntah yang dapat menurunkan asupan nutrisi.

Berdasarkan analisis univariat ini menunjukkan bahwa sebagian responden menjalani siklus kemoterapi pertama. Siklus kemoterapi menunjukan periode frekuensi pemberian regemen kemoterapi. Semakin banyak siklus yang sudah dijalani berarti dapat diketahui berapa periode yang sudah dijalani dan berapa frekuensi pemberian serta jenis regimen yang digunakan. berdasarkan analisa data sebagian besar respondon siklus pertama kemoterapi dan menggunakan regimen CAF (cyclophosphamide, dexorubisin, fluorourasil). Ketiga obat ini memberikan efek samping depresi sumsum tulang dan mual muntah. Depresi sumsum tulang dapat menimbulkan anemia. Mual muntah merupakan salah satu penyebab menurunnya asupan nutrisi responden (Polovich, Whitford, \& Olsen, 2008).

Berdasarkan analisis univariat menunjukkan bahwa rerata responden memiliki dengan kadar hemoglobin 11,57 gr/dl. Hemoglobin berfungsi mengikat oksigen yang akan didistribusi keseluruh tubuh. Oksigen berfungsi dalam proses oksidasi yang menghasilkan energi Hemoglobin terdapat dalam eritrosit (Sherwood, 2014). Pada pasien kanker mengalami depresi sumsum tulang sebagai salah satu efek samping kemoterapi, mudah mengalami perdarahan, menurunnya asupan

Sapti Ayubbana' Akademi Keperawatan Dharma Wacana Metro. Email: sapti.ayubbana@gmail.com

Sari Narulita ${ }^{2}$ Program Studi Keperawatan Universitas Binawan Email: sari@binawan.ac.id 
Fatigue dan status nutrisi pada pasien dengan kanker payudara yang menjalani kemoterapi

nutrisi yang dapat menyebabkan menurunnya kadar hemoglobin. Tingginya nilai hemoglobin pada penelitian ini terjadi karena salah satu syarat untuk dapat menjalani kemoterapi adalah kadar hemoglobin $\geq 10 \mathrm{gr} / \mathrm{dl}$ (Manir, Bhadra, Kumar, Manna, Patra, \& Sarkar, 2012).

\section{SIMPULAN}

Hasil penelitian ini menunjukkan bahwa terdapat hubungan antara status nutrisi terhadap fatigue pada pasien kanker yang menjalani kemoterapi ( $p$-value $=0,03)$ dengan kekuatan koreasi sedang $(r=0,471)$.

\section{SARAN}

Perawat perlu memberikan intervensi mandiri keperawatan dengan memberikan tindakan kenyamana seperti pemberian aromaterapi guna menurunkan keluhan mual muntah akibat kemoterapi guna meningkatkan asupan makanan agar tidak mengalami penurunan staitus nutria dan menurunkan keluhan fatigue.

\section{DAFTAR PUSTAKA}

American Cancer Society. (2016). Breast Cancer Facts \& Figures 2015-2016. Atlanta: American Cancer Society.

American Joint Committee on Cancer. (2010). What is cancer staging. URL: http://www.cancerstaging.org/mission/whatis.ht $m l$.

Black, J. M., \& Hawks, J. H. (2014). Keperawatan medikal bedah: manajemen klinis untuk hasil yang diharapkan. Elsevier (Singapore).

Campos, M. P. D. O., Hassan, B. J., Riechelmann, R., \& Giglio, A. (2011). Cancer-related fatigue: a review. Revista da Associacao Medica Brasileira, 57(2), 211-219.

Ferguson, M., Capra, S., Bauer, J., \& Banks, M. (1999). Development of a valid and reliable malnutrition screening tool for adult acute hospital patients. Nutrition, 15(6), 458-464

International Agency for Research on Cancer. (2012). Estimated cancer incidence, mortality, and prevalence worldwide in 2012.
Kementerian Kesehatan Republik Indonesia. (2013). Riset kesehatan dasar. Jakarta: Badan Penelitian dan Pengembangan Kesehatan.

Manir, K. S., Bhadra, K., Kumar, G., Manna, A., Patra, N. B., \& Sarkar, S. K. (2012). Fatigue in breast cancer patients on adjuvant treatment: course and prevalence. Indian journal of palliative care, 18(2), 109.

Mariani, L., Vullo, S. L., \& Bozzetti, F. (2012). Weight loss in cancer patients: a plea for a better awareness of the issue. Supportive Care in Cancer, 20(2), 301-309.

Mendoza, T. R., Wang, X. S., Cleeland, C. S., Morrissey, M., Johnson, B. A., Wendt, J. K., \& Huber, S. L. (1999). The rapid assessment of fatigue severity in cancer patients: use of the Brief Fatigue Inventory. Cancer, 85(5), 11861196.

Miaskowski, C., \& Aouizerat, B. E. (2014). Contribution of sleep disturbance to cancer fatigue. In Impact of Sleep and Sleep Disturbances on Obesity and Cancer (pp. 169192). Springer, New York, NY

National Comprehensive Cancer Network. (2012). Clinical practice guidelines in oncology. NCCN Chronic Myeloge-nous Leukemia Guidelines.

National Comprehensive Cancer Network. (2014). Clinical practice guidelines in oncology (NCCN Guidenlines): cancer-related fatigue. NCCN.org.

Paramita, N. (2015). Uji kesahihan dan keandalan brief fatigue inventory (BFI) versi Bahasa Indonesia pada pasien kanker $=$ Validity and reliability of brief fatigue inventory (BFI)Indonesian Version in cancer patients. Tesis. Program Studi Kedokteran Fisik dan Rehabilitas. Universitas Indonesia

Polovich, M., Whitford, J., \& Olsen, M. (2008). Chemotherapy and biotherapy guidelines and recommendations for practice. Oncology Nursing Society

Potter, P.A., \& Perry, A.G. (2006). Buku ajar fundamental keperawatan . Jakarta: EGC

Sapti Ayubbana' Akademi Keperawatan Dharma Wacana Metro. Email: sapti.ayubbana@gmail.com

Sari Narulita ${ }^{2}$ Program Studi Keperawatan Universitas Binawan Email: sari@binawan.ac.id 
Reiner, A., \& Lacasse, C. (2006). Symptom correlates in the gero-oncology population. In Seminars in oncology nursing (Vol. 22, No. 1, pp. 20-30). WB Saunders.

Rosdahl, C. B., \& Kowalski, M. T. (2012). Buku ajar keperawatan dasar. Jakarta: EGC.

Ryan, J. L., Carroll, J. K., Mustian, K. M., Fiscella, K., \& Morrow, G. R. (2007). Mechanisms of cancer-related fatigue. The oncologist, 12(Supplement 1), 22-34.
Sánchez, L. K., Ugalde, M. E., Motola, K. D., \& Green, D. (2013). Gastrointestinal symptoms and weight loss in cancer patients receiving chemotherapy. British Journal of Nutrition, 109(5), 894-897.

Sherwood, L. (2014). Fisiologi manusia: dari sel ke sistem; Ed.8. Jakarta: EGCWang, X. S. (2008). Pathophysiology of cancer-related fatigue. Clinical journal of oncology nursing, $12(5$ Suppl), 11.

Wei, J. N., \& Li, S. X. (2018). The relationship between nutritional risks and cancer-related fatigue in patients with colorectal cancer fasttrack surgery. Cancer nursing, 41(6), E41-E47 